percentile. There is no evidence that raised H.D.L. levels are significant in relation to atherosclerosis. In 15 patients total serum cholesterol exceeded its 95 th percentile due to high V.L.D.L.-cholesterol levels, the L.D.L. cholesterol being normal or low.

We thank Professors J. Shillingford and J. F. Goodwin for permitting us to study patients under their care. The study was supponted by grants from the Medical Research Council and from Unilever Ltd. We thank Miss A. Petrie and Mr. John Dolan for help with statistical analyses and data processing.

\section{References}

Albrink, M. J., and Man, E. B. (1959). Archives of Internal Medicine, 103, 4 Albrink, M. J. (1973). Fournal of the American Dietetic Association, 62, 626. Antonis, A., and Bersohn, I. (1960). Lancet, 1, 998.

Beaumont, J. L. et al. (1970). Bulletin of the World Health Organization, 43, 891.

Blankenhorn, D. H., Chin, H. P., and Lau, F. Y. K. (1968). Annals of Internal Medicine, 69,21

Brown, D. F., Kinch, S. H., and Doyle, S. T. (1972). New England fournal of Medicine, 273, 947.

Carlson, L. A. (1960). Acta Medica Scandinavica, 167, 399.

Carlson, L. A., and Wahlberg, F. (1966). Acta Medica Scandinavica, 180, 307. Carlson, L. A., and Böttiger, L. E. (1972). Lancet, 1, 865.

Coronary Drug Project (1970). Fournal of the American Medical Association, 220, 996.

Cramp, D. G., and Robertson, G. (1968). Analytical Biochemistry, 25, 246.

Dyerberg, J., Bang, H. O., and Nielsen, J. A. (1970). Acta Medica Scandinavica, 187, 353 .
Enger, S. C., and Ritland, S. (1970). Acta Medica Scandinavica, 187, 365.

Fredrickson, D. S., Levy, R. I., and Lees, R. S. (1967). New England fournal of Medicine, 276, 34, 94, 148, 215, and 273

Fredrickson, D. S., and Levy, R. L. (1972). In Metabolic Basis of Inherited Disease, ed. J. B. Stanbury, J. B. Wyngaarden, and D. S. Fredrickson, 3rd edn. New York, McGraw-Hill.

Fredrickson, D. S., Gotto, A. M., and Levy, R. I. (1972). In Metabolic Basis of Inherited Disease, ed. J. B. Stanbury, J. B. Wyngaarden, and D. S. Fredrickson, 3rd edn., p. 493. New York, McGraw-Hill.

Fyfe, T., et al. (1971). Lancet, 2, 997.

Goldstein, J. L., et al. (1973). Fournal of Clinical Investigation, 52, 1533.

Gustafson, A., et al. (1972). Circulation, 46, 709.

Gustafson, A., et al. (1972). Circulation, 46, 709.

Hatch, F. T., and Lees, R. S. (1968). Advances in Lipid Research, 6,

Heinle, R. A., et al. (1969). American fournal of Cardiology, 24, 178.

Leren, P., and Haabrekke, O. (1971). Acta Medica Scandinavica,

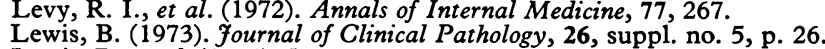

Lewis, B., et al. (1974). Lancet, 1, 141.

Mancini, M., et al. (1973). Atherosclerosis, 17, 445.

Micheli, H., et al. (1973). European fournal of Clinical Investigation, 3, 255.

Mills, G. L., and Wilkinson, P. A. (1966). British Heart fournal, 28, 638.

Nikkilä, E. A., and Aro, A. (1973). Lancet, 1, 954.

Patterson, D., and Slack, J. (1972). Lancet, 1, 393.

Rifkind, B. M., Lawson, D., and Gale, M. (1968). Fournal of Atherosclerosis Research, 8, 167.

Rosenman, R. H., et al. (1970). Fournal of Chronic Diseases, 23, 173.

Slack, J. (1969). Lancet, 2, 1380

Smith, E. B. (1957). Lancet, 2, 910.

Stamler, J. (1967). Lectures on Preventive Cardiology. New York, Grune and Stratton.

Tria, E., and Scanu, A. M. (1969). Structural and Functional Aspects of Lipoproteins in Living Systems. London and New York, Academic Press.

Truett, J., Cornfield, J., and Kannel, W. B. (1967). Fournal of Chronic Diseases, 20, 511

Tzagournis, M., et al. (1968). Circulation, 38, 1156.

Watson, W. C., Buchanan, K. D., and Dickson, C. (1963). British Medical Fournal, 2, 709.

\title{
Insulin Secretion in Malignant Hyperpyrexia
}

\author{
M. A. DENBOROUGH, \\ G. L. WARNE, \\ R. F. W. MOULDS, \\ P. TSE, F. I. R. MARTIN
}

British Medical fournal, 1974, 3, 493-495

\section{Summary}

An increased glucose-induced insulin response has been observed in patients susceptible to malignant hyperpyrexia. This raises the possibility that the membrane abnormality present in the calcium-storing membranes in the muscle cell in malignant hyperpyrexia may be present also in the beta cell of the pancreas.

\section{Introduction}

The syndrome of malignant hyperpyrexia is caused by a raised level of calcium ions in the myoplasm (Britt and Kalow, 1970; Denborough et al., 1973) which results from a rapid increased release of calcium from the calcium-storing membranes in the muscle cells of affected subjects, when exposed to general anaesthetics (Moulds and Denborough,

\footnotetext{
Department of Medicine, University of Melbourne, Melbourne, Australia

M. A. DENBOROUGH, M.D., F.R.A.C.P., Reader in Medicine (Present address: Department of Clinical Science, Australian National University, Canberra Hospital, Canberra, A.C.T. 2601, Australia)

F. I. R. MARTIN, M.D., F.R.A.C.P., Endocrinologist

R. F. W. MOULDS, B.MED.SCI., M.R.A.C.P., Research Fellow

G. L. WARNE, M.B., M.R.A.C.P., Assistant Endocrinologist

Department of Clinical Biochemistry, Royal Melbourne Hospital, Melbourne, Australia

P. TSE, M.SC., Biochemist
}

1974). The question arises whether other calcium-storing membranes in the body might be involved.

The work of Malaisse et al. has suggested that the regulation of insulin secretion depends on the level of calcium in the beta cells of the pancreas (Malaisse and Malaisse-Lagae, 1970), and these workers have drawn an analogy between the role of calcium in the release of insulin and its role in excitation-contraction coupling in muscle (Malaisse, 1973). This has prompted us to examine glucose-stimulated insulin secretion in patients with the myopathy predisposing to malignant hyperpyrexia.

\section{Subjects and Methods}

Intravenous glucose tolerance tests (G.T.T.) (glucose 0.75 $\mathrm{g} / \mathrm{kg}$ body weight to a maximum of $50 \mathrm{~g}$ ) were performed after overnight fasting on 13 patients who were susceptible to malignant hyperpyrexia and on 10 controls. The patients (who included three survivors from malignant hyperpyrexia) were identified by showing in vitro a highly abnormal sensitivity of the calcium-storing membranes in their muscle cells to halothane, suxamethonium, caffeine, and potassium chloride (Moulds and Denborough, 1974). Five of the controls were related to patients with malignant hyperpyrexia but their muscle gave a normal response to in-vitro pharmacological testing and they were considered to be unaffected by the disease; the other five were apparently healthy volunteers.

No subject was diabetic and only one myopathic patient was obese. All were receiving normal diets before testing and no one was taking other drugs. Only one subject, a healthy volunteer, gave a family history of diabetes. The 
mean ages of the patients and the controls were comparable (36 and 31 years respectively).

An indwelling intravenous catheter was used to collect blood at $0,2,5,10,15,20,30,40$, and 60 minutes after glucose. Blood sugar was measured on an AutoAnalyzer and plasma insulin levels were measured by radioimmunoassay using charcoal separation (Alford et al., 1971). Nine patients and five controls also had insulin tolerance tests (I.T.T.) after intravenous soluble insulin $0.1 \mathrm{unit} / \mathrm{kg}$ (Alford et al., 1971).

\section{Results}

The mean plasma insulin levels were significantly higher in the patients than in the controls at $2,5,10,15,20,30$, and 60 minutes after glucose (see fig.). The mean values for fasting plasma insulin and at $\mathbf{4 0}$ minutes after glucose were also higher in the affected group though the differences were not statistically significant (see table).

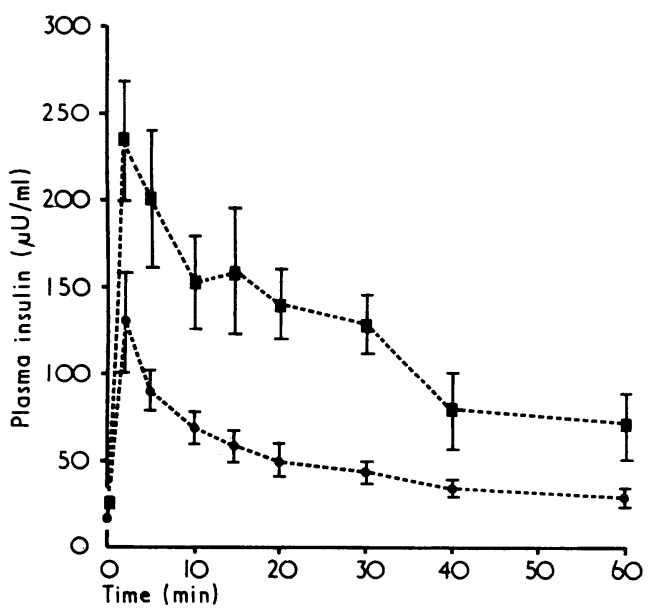

Plasma insulin levels after glucose load in patients with malignant hyperpyrexia (D) and in controls ( $O$ ) Results are shown as mean values and standard errors of means.

When considering the area under the curve for plasma insulin (see table) the value for the affected group was significantly higher overall and for the periods of 0-10 and 10-60 minutes.

Glucose tolerance $\left(\mathbf{K}_{\text {G.r.T. }}\right)$ was not significantly different between the patients and the controls and only the obese patient showed subnormal glucose tolerance $\left(\mathrm{K}_{\text {G.r.T. }}=0.5\right)$. There was no significant difference in insulin tolerance between the two groups. The mean $\mathrm{K}_{\text {I.T.r. }}$ in the patients was 4.98 (S.D. 2.09) and in the controls 7.55 (S.D. 3.46) $(t=$ $1.67, \mathrm{P}>0.1)$. In the patients insensitivity to insulin $\left(\mathrm{K}_{\text {I.T.r. }}\right)$ was not significantly correlated with either a high insulin peak $(r=0.340, P>0.1)$ or a large area under the curve $(r=0.329, P>0.1)$.

\section{Discussion}

These results show that patients with the malignant hyperpyrexia myopathy have higher plasma levels of insulin than normal after a glucose load. The findings that insulin tolerance was not significantly abnormal in the malignant hyperpyrexia patients and that there was no significant correlation between insulin tolerance and plasma insulin levels after glucose suggest that in these patients the raised plasma insulin levels were not due to insulin resistance. One possible explanation for the raised immunoreactive insulin levels would be an increased secretion of an insulin-like molecule such as proinsulin, which has less biological activity than normal insulin, and this possibility is being examined. There is also an increased secretion of insulin in response to a glucose load in dystrophia myotonica (Huff et al., 1967), which is probably also due to a muscle membrane abnormality, and in these patients the insulin:proinsulin ratio is normal (Kagan et al., 1969).

The release of calcium from the calcium-storing membranes in the muscle cells in malignant hyperpyrexia is greater than normal in response to a variety of pharmacological agents (Moulds and Denborough, 1974), and our findings suggest that this membrane abnormality in malignant hyperpyrexia may not be confined to the muscle cells but may also be present in the beta cells of the pancreas. Malaisse has proposed the hypothesis that the level of calcium in the beta cell may be the single mediating factor in the secretion of insulin caused by various agents including glucose. The findings of this investigation are consistent with the presence of a membrane abnormality in the beta cell in subjects who are susceptible to malignant hyperpyrexia, so that glucose induces a higher level of calcium in the beta cell than normal and thus a larger secretion of insulin. The presence of circulating anti-insulin factors or abnormal insulin receptor sites, however, cannot be excluded.

R. F. W. Moulds is a postgraduate research scholar of the National Health and Medical Research Council of Australia. We are indebted to Miss B. Laby, of the University of Melbourne, for

Summary of Calculations

\begin{tabular}{|c|c|c|c|c|c|c|c|c|c|}
\hline \multirow{2}{*}{ Time (Minutes) } & \multicolumn{3}{|c|}{ Malignant Hyperpyrexia Patients } & \multicolumn{3}{|c|}{ Controls } & \multirow{2}{*}{$t$ 'Value } & \multicolumn{2}{|c|}{ Significance Level L $†$} \\
\hline & $\mathbf{n}$ & Mean Value & S.D. & $\mathbf{n}$ & Mean Value & S.D. & & $5 \%$ & $1 \%$ \\
\hline $\begin{array}{r}0 \\
2 \\
5 \\
10 \\
15 \\
20 \\
30 \\
40 \\
60\end{array}$ & $\begin{array}{l}13 \\
13 \\
13 \\
12 \\
10 \\
13 \\
13 \\
11 \\
13\end{array}$ & $\begin{array}{r}26 \cdot 1 \\
234 \cdot 1 \\
199 \cdot 2 \\
151 \cdot 5 \\
157 \cdot 5 \\
126 \cdot 2 \\
109 \cdot 4 \\
78 \cdot 5 \\
69 \cdot 7\end{array}$ & $\begin{array}{r}14 \cdot 2 \\
126 \cdot 4 \\
134.9 \\
94.7 \\
113.8 \\
92 \cdot 2 \\
84.9 \\
77 \cdot 7 \\
67 \cdot 0\end{array}$ & $\begin{array}{c}\text { sma Insulin Leve } \\
10 \\
10 \\
10 \\
10 \\
10 \\
10 \\
10 \\
10 \\
10\end{array}$ & $\begin{array}{r}s(\mu \mathrm{U}) \\
17.4 \\
130.7 \\
90.3 \\
68.3 \\
57.2 \\
49.6 \\
41.9 \\
33.1 \\
26.6\end{array}$ & $\begin{array}{l}12 \cdot 6 \\
89.5 \\
41 \cdot 3 \\
28 \cdot 3 \\
26 \cdot 5 \\
22.0 \\
21 \cdot 3 \\
15 \cdot 8 \\
15 \cdot 1\end{array}$ & $\begin{array}{l}1.55 \mathrm{~N} . S . \\
2 \cdot 30 * \\
2 \cdot 75 * \\
2 \cdot 89 * \\
2 \cdot 71 * \\
2 \cdot 89 * \\
2 \cdot 74 * \\
1 \cdot 89 \mathrm{~N} . S . \\
2 \cdot 24 *\end{array}$ & $\begin{array}{l}2 \cdot 22 \\
2 \cdot 21 \\
2 \cdot 19 \\
2 \cdot 21 \\
2 \cdot 26 \\
2 \cdot 19 \\
2 \cdot 19 \\
1 \cdot 90 \\
2 \cdot 18\end{array}$ & \\
\hline $\begin{array}{r}0-10 \\
10-60 \\
0-60\end{array}$ & $\begin{array}{l}13 \\
13 \\
13\end{array}$ & $\begin{array}{l}1,856 \\
5,200 \\
7,056\end{array}$ & $\begin{array}{l}1,003 \\
3,736 \\
4,471\end{array}$ & $\begin{array}{c}\text { Area under Cu} \\
10 \\
10 \\
10\end{array}$ & $\begin{array}{r}902 \\
2,080 \\
2,983\end{array}$ & $\begin{array}{r}427 \\
947 \\
1,268\end{array}$ & $\begin{array}{l}3 \cdot 08 * \\
2 \cdot 89 * \\
3 \cdot 13^{* *}\end{array}$ & $\begin{array}{l}2 \cdot 19 \\
2 \cdot 19 \\
2 \cdot 19\end{array}$ & $\begin{array}{l}3.09 \\
3.07 \\
3.07\end{array}$ \\
\hline
\end{tabular}

N.S. = Not significant.

Significant at $5 \%$ level.

$+L=\left(W_{1} t_{1}+W_{2} t_{2}\right) /\left(W_{1}+W_{2}\right)$.

$W_{1}=S_{1} n_{1}$ (patients); $W_{1}=W_{2}^{2} / n_{2}$ (controls).

$S_{1}=$ variance (patients); $S_{2}=$ variance (controls).

$t_{1}$ is $5 \%$ value of $t$ from tables with $n_{1}-1 D . F$.

$t_{2}$ is $5 \%$ value of $t$ from tables with $n_{2}-1 D$.F. 
the statistical analysis. We are also grateful to the Victor Hurley Research Fund of the Royal Melbourne Hospital for support and to Mrs. K. Myles and Miss J. Gray for expert technical help.

\section{References}

Alford, F. P., Martin, F. I. R., and Pearson, M. J. (1971). Diabetologia, 7, 173. Britt, B. A., and Kalow, W. (1970). Canadian Anaesthetists' Society fournal, 17,316 .
Denborough, M. A., et al. (1973). In International Symposium on Malignant Hyperthermia, ed. A. Gordon, B. A. Britt, and W. Kalow, p. 229. Springfield, Illinois, Thomas.

Huff, T. A., Horton, E. S., and Lebovitz, H. E. (1967). New England fournal of Medicine, 277, 837

Kagan, A., Brunner, N. G., and Grob, D. (1969). Clinical Research, 17, 286. Malaisse, W. J. (1973). Diabetologia, 9, 167.

Malaisse, W. J., and Malaisse-Lagae, F. (1970). Acta Diabetologica Latina, 7, Suppl. No. 1, p. 264

Moulds, R. F. W., and Denborough, M. A. (1974). British Medical fournal,

Snedecor, G. W., and Cochran, W. G. (1967). Statistical Methods, 6th edn., p. 114. Ames, Iowa State University Press.

\title{
Familial Clustering of Hepatitis B Antigen: A Study in Relatives of Patients with Liver Diseases and Hepatitis B Antigenaemia
}

\author{
MIGUEL BRUGUERA, JAIME BOSCH, JUAN RODÉS， JOSE PEDREIRA
}

British Medical fournal, 1974, 3, 495-497

\section{Summary}

Twelve of the 100 family contacts of 29 patients with transient and persistent hepatitis $B$ antigenaemia were found to be positive for hepatitis $B$ antigen (HBAg). No relation was found between familial clustering and the nature of liver disease or the duration of antigenaemia in the index cases.

Eight affected relatives were apparently healthy carriers of HBAG, one had cirrhosis, and three (in the same family) developed acute viral hepatitis.

The absence of parenteral exposure in the HBA,-positive family contacts and the identity in antigenic determinants $d$ or $y$ with those of the index cases, suggest a nonparenteral spread of $\mathrm{HBAg}$ in families of patients with HBAg-associated liver diseases.

\section{Introduction}

Nonparenteral transmission of viral hepatitis type B has been reported by several investigators (Krugman et al., 1967; Koff and Isselbacher, 1968; Giles et al., 1969). Krugman and Giles (1970) showed that long-incubation hepatitis could be transmitted orally under controlled conditions, and some reports have suggested other noutes of transmission such as airborne (Almeida et al., 1971; Garibaldi et al., 1972), venereal (Hersh et al., 1971; Fulford et al., 1973; Heathcote and Sherlock, 1973; Jeffries et al., 1973), and transplacental (Schweitzer et al., 1973). In most cases of hepatitis B without parenteral exposure, however, the exact mode of transmission of the disease cannot be determined.

The familial clustering of carriers of hepatitis $B$ antigen (HBAg) provides epidemiologic evidence of nonparenteral

Liver Unit, University of Barcelona, Hospital Clinico y Provincial Barcelona, Spain

MIGUEL BRUGUERA, M.D., Physician

JAIME BOSCH, M.D., Physician

JUAN RODES, M.D., Director of the Liver Unit

Department of Medicine, University Autonoma of Barcelona, Ciudad Sanitaria de la Seguridad Social, Barcelona, Spain JOSE PEDREIRA, M.D., Physician spread of the hepatitis virus B. Szmuness et al. (1973) and Berris et al. (1973) have shown that the spread of hepatitis B infections among relatives of asymptomatic blood-donor carriers is considerable, but the incidence of familial clustering among relatives of patients with acute and chronic liver diseases with hepatitis $B$ antigenaemia has not yet been assessed.

We report here the findings of a survey done to evaluate the incidence of HBAg in family units of Spanish patients with $\mathrm{HBAg}$-positive liver diseases.

\section{Patients and Methods}

The series included 100 of the 108 household relatives of 29 partients, (index cases) with HBAg-positive liver diseases (12 acute viral hepatitis, nine chnonic hepatitis, and eight cirhosis) admitted to the liver unit of the Hospital Clinico y Provincial, Barcelona.

Screening for HBAg was carried out by countercurrent electrophoresis (Pesendorfer et al., 1970). Subtyping was performed by two-dimensional agar gel diffusion (Prince, 1968) using human monospecific ad and ay antiserums. These antiserums showed identity lines against reference antigens from Y. Cossart, Virus Reference Laboratory, London. Transaminase activity was determined by the kinetic spectrophotometric method (Wroblewski and La Due, 1956).

A personal interview was held in all cases to exclude other possible sources of exposure to the hepatitis B virus-for example, blood transfusions, injections with a shared needle, vaccinations, surgical or dental procedures, tattooing, or contact with cases of hepatitis other than the affected relatives.

\section{Results}

Twelve of the 100 relatives investigated were found to be antigen carriers. Clustering of HBAg occurred in nine $(31 \%)$ of the 29 families. The number of contacts in these nine families was 39, showing a prevalence of $\mathrm{HBAg}$ of $31 \%$.

No relation was found between the nature of liver disease in the index cases and the presence of hepatitis B antigenaemia in the relatives (table $I$ ). The frequency of detection of HBAg varied between specific relatives of the index cases (table II). The highest incidence was among offspring though it was not significantly different from that found in spouses. Non-blood relatives other than spouses did not present $\mathrm{HBAg}$ in the serum. 